\title{
All Normal Occupations are Sunny and Joyful: Qualitative Analysis of Thai Ladyboys' Occupational Wellbeing
}

\author{
Bei Lyu (D) ${ }^{1,2}$ \\ Wenwen $\mathrm{Li}^{1}$ \\ Mingyu $\mathrm{Xu}^{\prime}$ \\ Hui Chen ${ }^{2,3}$ \\ Yanchao Yang (D) ${ }^{4}$ \\ 'School of Economics and Management, \\ Huaibei Normal University, Huaibei, \\ 235000, People's Republic of China; \\ ${ }^{2}$ Chinese Graduate School, Panyapiwat \\ Institute of Management, Nonthaburi, \\ II 120, Thailand; ${ }^{3}$ School of Management, \\ Suzhou University, Suzhou, 234000 \\ People's Republic of China; ${ }^{4}$ Faculty of \\ Education, University of Macau, Macau, \\ 999078, People's Republic of China
}

Correspondence: Bei Lyu; Wenwen Li, School of Economics and Management, Huaibei Normal University, Huaibei, 235000, People's Republic of China $\mathrm{Tel}+86$ 13770838193

Email peter1983123@hotmail.com
Background: As the modern social division of labour is becoming increasingly specified, various occupations have emerged. Ladyboy, as a special occupation, is receiving a surging amount of attention from society and academia. Ladyboy is an individual who is engaged in performing with female psychology but still retains male sexual characteristics, and this special characteristic has an impact on their occupational identity and occupational satisfaction.

Methods: This study investigated the current situation of ladyboys' occupational wellbeing through interviews, and analyzed and coded the interview texts via Nvivo 11.0 guided by Grounded Theory.

Results: Through open coding, axial coding, and selective coding, the study found that ladyboys' occupational wellbeing was generally high, and they were still full of love and confidence in their occupation even in the context of the COVID-19 epidemic.

Conclusion: Concurrently, the study also found that for the profession of ladyboy, there are still many areas for improvement in society, such as the lack of supporting facilities, absence of supportive and protective policies, and unemployment livelihood security, etc. Feasible measures were then proposed for these specific problems.

Keywords: gender identity, ladyboy, occupational wellbeing, re-employment

\section{Problem Statement and Literature Review}

As the division of labor in society becomes increasingly specified, a mushrooming number of diversified occupations emerged. Currently, according to the standard set by the International Labor Organization, ${ }^{1}$ the occupational categories consists of 8 Major groups, 83 Minor groups, 284 Unit groups, and 1506 Occupational categories. The eight Major categories are Occupational, Technical and Related Workers, Administrative and Managerial Workers, Clerical and Related Workers, Sales Workers, Service Workers, Agricultural, Animal Husbandry, and Forestry Workers, Fishermen and Hunters and Production and Related Workers, Transport Equipment Operators and Labourers, Workers Not Classifiable by Occupation. Diverse occupational characteristics of different occupations exert a distinctive impact on occupational wellbeing. Meanwhile, to meet the needs of the understanding of the international standard classification of occupations (2008), the International Labour Organization distinguishes between "occupation" and "work", and contends that "job" is "the sum of tasks and responsibilities that a person passively (or actively) undertakes for the employer (or self-employed)", 
while "occupation" is "the sum of jobs with highly similar main tasks and responsibilities" Therefore, occupation does not specifically refer to an activity or task to make a living, but the synthesis of a series of similar activities, which represents the development direction of individual choice. Therefore, occupation not only meets the current material needs of individuals but also has an impact on their spiritual life and work psychology, making individuals have a sense of occupational happiness.

Occupational wellbeing refers to the overall emotional experience and comprehensive evaluation of the practitioner's occupation in terms of emotion, motivation, behavior, cognition, and physical and mental wellbeing, ${ }^{3}$ which is the subjective feeling of satisfying one's professional goals and living standard through work, ${ }^{4}$ which runs through the whole career of practitioners. It is emphasized that this feeling is brought by long-term work experience rather than short-term or temporary, ${ }^{5}$ and it is integrated into the practitioner's entire career. According to Sun, occupational wellbeing consists of four aspects, which are the practitioner's evaluation of the subordinate occupation, the emotional working experience, the satisfaction with the working environment, and the continuous occupational experience. ${ }^{6}$ With the specialization of labor, the research focuses from home and abroad on occupational wellbeing have become increasingly specific. A close look at the existing literature reveals that the current research on occupational wellbeing is mainly divided into three categories: occupation-based research, gender-based research, and factor-identification-based research. Occupation-based research is mainly focused on teachers, ${ }^{7}$ police officers, and nursing workers, while gender-based research, on the other hand, mainly concluded that occupational practitioners with higher gender identity have higher occupational wellbeing and gender discrimination can lead to inappropriate tasks, which affects the level of occupational wellbeing of practitioners. $^{8-11}$ In addition, more studies are focusing on influencing factors, such as the positive correlation between practitioners' motivation and occupational well-being, ${ }^{12}$ emphasis on occupational health services and psychosocial safety services for employees as one of the significant ways to enhance employees' occupational well-being, ${ }^{13}$ positive correlation between employees' occupational wellbeing and qualified competencies or knowledge base, positive selfintervention, ${ }^{14}$ and the impact of occupational stress ${ }^{15}$ and working environment on practitioners' occupational wellbeing. ${ }^{16}$ In-depth research and analysis of specialization of occupation and occupational wellbeing reveal that ladyboy has the above three characteristics and is well worth exploring.

Through the survey, it is found that ladyboys exist in many countries, but the representative country that has promoted it as a profession is Thailand. In Thailand, ladyboys can be divided into three categories: the first category includes those who like to dress femininely in daily life, imitate girls psychologically and behaviorally, and are active in women's circles, but are still essentially male. The second category refers to those who usually take estrogen to inhibit male sexual characteristics since childhood. Although male organs are still preserved physiologically, they have been completely feminized psychologically and are usually active in performing in major scenic spots in Thailand. The third group is those who have undergone sex reassignment surgery and have completely feminized their bodies and other physical characteristics. ${ }^{17}$ The profession of ladyboy in this paper refers to the second category. As a profession, ladyboys will be affected by their special emotional experience, especially when ladyboys' gender is not yet unified. Although they are completely feminized mentally and physically, their identity information is still male. Therefore, this paper focuses on ladyboys, aims to study whether gender ambiguity will affect their career wellbeing, by using NVivo 11 to conduct a qualitative study on ladyboys' occupational wellbeing, analyzes the current situation, and puts forward targeted suggestions.

\section{Research Design \\ Research Methodology}

Grounded Theory is a classical paradigm of qualitative research, which requires researchers to progressively summarize and analyze the observed first-hand data without theoretical assumptions, and to finally construct theory via three-level coding stages. This is a bottom-up theoretical method, which extracts the core concepts (elements) based on information analysis. Its key feature is to establish new concepts and ideas. This extraction can reflect the whole picture of the research topic, but it loses a lot of information, fails to make full use of information or mine information, which is a major shortcoming of qualitative analysis. The vitality of research lies in continuous innovation, and so does research methodology. ${ }^{18,19}$ The research instrument of qualitative research is the researcher himself, and the data are collected and analyzed through multiple means (eg, interviews, textual analysis, etc.) to produce a holistic 
grasp of the research object. There are various methods of qualitative research analysis, and sometimes a combination of them can be used. The common methods of analysis are category analysis and situational analysis, and the method used in this paper is category analysis. "Category analysis is the process of comparing data, finding and interpreting multiple occurrences of data, and constructing a gradient of themes". It is the process of coding that is referred to in Grounded theory. Originally proposed by Claser and Strauss, the coding method currently used is still the "Corbin \& Strauss path" proposed by Strauss et al ie, open coding, axial coding, and selective coding. Open coding requires the researcher to always maintain theoretical objectivity, and to integrate the original data obtained in the research process with an open mind, and to organize them according to their original concepts, with the aim of initial conceptual categorization and clarification of the categories; axial coding further focuses based on open coding and makes the coding more directional, selective, and the selective coding is based on the analysis of the axial coding and the established concepts as well as categories, and further refining the interrelationships, to construct the framework of the theoretical model. ${ }^{20}$

This paper adopted a qualitative research method, semistructured interviews, to explore the theoretical structure of ladyboys' occupational wellbeing, following the systematic procedures of Grounded Theory. The coding procedure adopted is the "Strauss and Corbin path", namely open coding, axial coding, and selective coding, created by Strauss et al. ${ }^{21}$ The coding procedure is less restrictive and more operational, thus enabling progressive and in-depth theory construction systematically. Open coding requires researchers to always remain theoretically objective, and with an open mind, to integrate the original data obtained in the research process in the same category, and to sort out the original concept according to its original concept, the purpose is to initially classify the concept and clarify the scope; The core coding is further focused on the basis of the open coding, and the classification of the initial category is again made to make the coding more directional, selective and conceptual; the selective coding is based on the analysis of the axis coding, based on the established concept And the category, further refine the interrelationship, to construct the framework of the theoretical model.

\section{Data Sources and Participants}

The research object of this paper is mainly the ladyboys engaged in the performance. The researchers found a performance team in Pattaya on April 7, 2020, with a total of more than 20 people. 20 ladyboys in Pattaya were contacted and 8 were unwilling to be interviewed due to privacy concerns. Finally, 12 ladyboys participated in the study, who were labeled as L1 to L12. However, some practitioners are unwilling to accept the interview due to fear of divulging privacy, the conflict between interview time and performance time, dissatisfaction with the remuneration given by the researchers, and other reasons.

The basic situation of the participants is shown in Table 1: (1) among the twelve participants, the youngest is 18 years old and the oldest is 25 years old, which is in line with the widely acknowledged working age for ladyboys engaged in performance; (2) the shortest working period is one year and the longest is five years; (3) during non-performance time, three ladyboys wear men's clothes and the other nine wear women's clothes, but they are all psychologically female. (4) In terms of family status, five ladyboys have poor family economic status and seven have good family status. See more details in Table 1.

\section{Research Procedure Data Collection}

The data was collected mainly via semi-structured interviews. Firstly, the interview outline was designed through Delphi Interview Method, and two participants were selected for preliminary interviews, and the outline was further revised and improved. The interview questions include, but are not limited to basic personal information (age, gender identity, years of working experience, family financial situation, etc.), how they view their profession, whether they are voluntary or arranged by their family, whether they are willing to work as ladyboys, and what impact the current epidemic will have on their profession. Secondly, consent was sought from the participants prior to the interview and they were assured that private information and the content of the interview would be kept confidential and would only be used for academic purposes. Finally, formal interviews were conducted, data were collected using both audio recordings and notes, and all data were transcribed into text form and coded and analyzed using Nvivo 11.0.

\section{Qualitative Coding Open Coding}

The transcribed interview data were imported into the Nvivo 11.0 and coded and guided by Grounded Theory. The first step was open-ended coding. The primary data 
Table I More Detail About Participants

\begin{tabular}{|c|c|c|c|c|c|c|c|}
\hline No. & Age & $\begin{array}{l}\text { Psychological } \\
\text { Gender }\end{array}$ & $\begin{array}{l}\text { Dressing } \\
\text { Preference }\end{array}$ & $\begin{array}{l}\text { Length of } \\
\text { Employment }\end{array}$ & $\begin{array}{l}\text { Family Financial } \\
\text { Status }\end{array}$ & $\begin{array}{l}\text { Taking } \\
\text { Estrogen }\end{array}$ & $\begin{array}{l}\text { Sex } \\
\text { Change }\end{array}$ \\
\hline LI & 18 & Female & Male dress & Less than one year & Good & Yes & No \\
\hline L2 & 18 & Female & Male dress & Less than one year & Good & Yes & No \\
\hline L3 & 19 & Female & Male dress & Less than one year & Good & Yes & No \\
\hline L4 & 20 & Female & Female dress & Two years & Poor & Yes & No \\
\hline L5 & 22 & Female & Female dress & Two years & Good & Yes & No \\
\hline L6 & 22 & Female & Female dress & Four yeas & Poor & Yes & No \\
\hline L7 & 22 & Female & Female dress & Four yeas & Poor & Yes & No \\
\hline L8 & 23 & Female & Female dress & Four yeas & Good & Yes & No \\
\hline L9 & 23 & Female & Female dress & Three years & Good & Yes & No \\
\hline LIO & 23 & Female & Female dress & Five years & Poor & Yes & No \\
\hline LII & 23 & Female & Female dress & Five years & Poor & Yes & No \\
\hline LI2 & 25 & Female & Female dress & Five years & Good & Yes & No \\
\hline
\end{tabular}

were analyzed step-by-step to comprehensively explore statements about ladyboys' occupational wellbeing to identify concepts and read repeatedly to ensure no new concepts could be formed. The refined concepts were coded and named by referring to the literature with the representative keywords mentioned in the interviews, initially forming more than 200 original statements needed for the study. Then, by using Nvivo's Category coding function, similar statements from interview responses to similar questions were combined and reorganized to categorize the concepts to form a category. At last, 16 categories were obtained as shown in Table 2, namely "harmonious relationship", "family support", "social identity", "gender ambiguity", "sense of belonging", "gender identity", "selfaffirmation", "access to wealth", "supporting facility", "physical and mental health", "working for a living", "active engagement", "love for work", "psychological satisfaction", "fulfillment of life values", "career aspirations".

\section{Axis Coding}

To form a more comprehensive and conceptual coding, axial coding was conducted, through which, based on open coding, the extracted concepts were further clustered and analyzed to discover and establish links between the various categories, thus forming more comprehensive and general categories to gain a holistic view.
After several comparisons, the 16 categories were sorted into five main categories as shown in Table 2, namely "social support", "self-identity", "welfare protection", "physical and mental experience", and "social support". "physical and mental experience" and "self-worth".

\section{Selective Coding}

Next, comprehensive and conceptual extraction was carried out to refine the core categories among the existing categories. The core categories were also selectively coded by linking them to other categories and completing the categories not yet extracted by the conceptualization. The coding information from both the open and axial coding stages was used to refine, reorganize and verify that there is no repetitive coding, unexampled coding, or logical intersections between the sub-nodes within each category and between the nodes within the category. Then, four categories regarding "ladyboys' occupational wellbeing" were constructed as shown in Table 3, namely "social dimension", "spiritual dimension", "material dimension", and "demographic information".

\section{Research Results and Discussion Research Results}

By sorting and coding the text data, 16 sub node categories were formed in the open coding stage, which was further summarized into five categories in the axis coding stage. 
Table 2 Axis Coding

\begin{tabular}{|c|c|c|c|c|}
\hline Categories & Concept & Source & Node & Example \\
\hline \multirow[t]{4}{*}{$\begin{array}{l}\text { Social support } \\
47\end{array}$} & $\begin{array}{l}\text { Harmonious } \\
\text { relationship }\end{array}$ & 8 & 12 & I like to be with them and they help me very much. \\
\hline & Family support & 5 & 10 & My parents are teachers (doctors). They understand my choice. \\
\hline & Social identity & 5 & 9 & We make money from our own performances and will not be ridiculed and despised. \\
\hline & $\begin{array}{l}\text { Gender } \\
\text { ambiguity }\end{array}$ & 6 & 16 & I am a girl. Why do they ask me to do this? \\
\hline \multirow[t]{3}{*}{$\begin{array}{l}\text { Self-identity } \\
51\end{array}$} & $\begin{array}{l}\text { Sense of } \\
\text { Belonging }\end{array}$ & 6 & 15 & I have lived in the circle of women since I was a child. I feel like a woman. \\
\hline & $\begin{array}{l}\text { Gender } \\
\text { identity }\end{array}$ & 10 & 14 & I do not hate my male sexual characteristics. \\
\hline & $\begin{array}{l}\text { Self- } \\
\text { affirmation }\end{array}$ & 14 & 22 & We are also very normal people, and our status does not matter. \\
\hline \multirow{4}{*}{$\begin{array}{l}\text { Welfare } \\
\text { protection } \\
30\end{array}$} & $\begin{array}{l}\text { Access to } \\
\text { wealth }\end{array}$ & 9 & 10 & I think this job is very good. It can bring money. \\
\hline & $\begin{array}{l}\text { Supporting } \\
\text { facilities }\end{array}$ & 9 & 10 & I go to the women's bathroom and sometimes feel embarrassed. \\
\hline & $\begin{array}{l}\text { Physical and } \\
\text { mental health }\end{array}$ & 4 & 5 & Using hormones, living habits will cause harm. Work harder when you are young. \\
\hline & $\begin{array}{l}\text { Working for } \\
\text { a living }\end{array}$ & 5 & 5 & $\begin{array}{l}\text { Forced to make a living, their parents sent them to the ladyboy school to accept } \\
\text { physical and psychological changes. }\end{array}$ \\
\hline \multirow{3}{*}{$\begin{array}{l}\text { Physical and } \\
\text { mental } \\
\text { experience } \\
76\end{array}$} & $\begin{array}{l}\text { Active } \\
\text { engagement }\end{array}$ & 8 & 30 & When people feel happy, they do not feel hard to work. \\
\hline & Love for work & 8 & 23 & If I feel happy at work, I will not have pressure. I am very happy. \\
\hline & $\begin{array}{l}\text { Psychological } \\
\text { satisfaction }\end{array}$ & 7 & 23 & My present job makes me feel very happy. \\
\hline \multirow[t]{2}{*}{$\begin{array}{l}\text { Self-worth } \\
32\end{array}$} & $\begin{array}{l}\text { Fulfilment of } \\
\text { life values }\end{array}$ & 5 & 8 & $\begin{array}{l}\text { The moment fireworks bloom is the short life of fireworks. People like us enjoy life in } \\
\text { the best youth. There is nothing to be sad about in life. }\end{array}$ \\
\hline & $\begin{array}{l}\text { Career } \\
\text { aspirations }\end{array}$ & 10 & 24 & Being a woman is my dream \\
\hline
\end{tabular}

The framework for Ladyboys' Occupational Wellbeing was established based on the theme of "ladyboys' occupational wellbeing". As can be seen from Table 3, the framework for ladyboys' occupational wellbeing mainly includes four aspects: "social dimension", "spiritual dimension", "material dimension", and "demographic information", among which spiritual dimension is prominently based on the highest number of source of reference materials and nodes in the category, 108, which reflects that most of the ladyboys are satisfied with their careers and have a high sense of happiness.

\section{Validity Test}

The research tool of qualitative research is the researcher himself and his team, and data collection is through the two-way interaction between the researcher and the participants. Therefore, to avoid too strong subjectivity and to keep the research results close to the real situation is the main standard to test the effectiveness of the research results.

Firstly, one of the researchers is an instructor with a doctoral degree who has studied and lived in Thailand for many years, who has a better understanding of the 
Table 3 Selective Coding

\begin{tabular}{|l|c|}
\hline Categories in Axial Coding & Categories in Selective Coding \\
\hline Social support & Social dimension \\
Self-identity & 98 \\
\hline Welfare protection & Material dimension \\
& 30 \\
\hline Physical and mental experience & Spiritual dimension \\
\hline Self-worth & Demographic information \\
\hline Age & \\
\hline Psychological gender & \\
\cline { 1 - 1 } Family financial status & \\
\hline
\end{tabular}

occupation of Thai ladyboy, and has relevant network resources. Another researcher is a psychological counselor, who has strong empathy and solid interview skill, which enables him to be closer to the real world of ladyboys and to understand their real feelings, thus enabling them to fully express themselves in a reassuring environment. Secondly, the original data were fully tested, and the research results and interpretation were based on the original data. The researcher collected the original data through the interview, carried out coding, and conducted analysis and induction repeatedly. In addition to recording the answers of the respondents, the researcher also summarized the situation and feelings of the interview afterward, to more truly express the situation of the participants in the subsequent analysis. Finally, Delphi Interview Method was used from the design of the interview outline for succeeding coding analysis. Four experts were invited to give feedback in the whole process of the research, and the interview outline, original data, coding, and category were tested and revised according to experts' opinions, to make the research results more authentic and reliable. Therefore, this study can accurately approach the real situation of the participants with good validity, effectiveness, and credibility.

\section{Demographic Information}

Although the survey was designed with a large number of components, a review of the results and literature reveals that the three categories that have a strong influence on the profession of ladyboys are age, psychological gender, and family economic situation. ${ }^{22}$ Firstly, the occupation of ladyboy has a similar high requirement for age to that of other performing professions, which is between the ages of 18 and 28 , when they are more physically fit and have a good appearance, thus being more popular. However, the longterm use of estrogen to maintain their female sexuality and concern for the negative effect of aging on their appearance can lead to a decline in their physical functions later in life, which can be life-threatening. The second is psychological gender. The psychological gender of all the ladyboys surveyed was female, and although three of them wore men's clothes in their daily lives, they all considered themselves to be girls and felt that they should have been girls since they were very young. In this respect, it is consistent with the definition of ladyboy derived from the previous literature analysis, ie people who are fully feminized psychologically although still retaining male organs physically. Several participants even mentioned that they would still like to undergo gender reassignment surgery if they had the chance, to become physically female. Finally, the third emerging demographic information is their family financial situation. It is usually perceived that ladyboys are engaged in this profession because their families are very poor and that it is easier for girls to earn money in Thailand so that they can support their families. However, it is found that only five out of the 12 participants were in a slightly poorer financial situation and needed to earn their own money to support their families. More of the respondents had family members who worked as teachers, lawyers, doctors, engineers, etc., and whose families were more financially well off. They chose this profession more because they liked the identity and wanted to live like a girl, which was their dream career choice, and this was verified in the later interviews.

\section{The Spiritual Dimension}

The spiritual dimension consists of two main categories, namely physical and mental experience, and self-worth. The meaning of the two dimensions is the spiritual satisfaction embodied by the profession of ladyboys, mainly in terms of whether their occupational aspirations are realized and whether this job brings the emotional experience, which is also the objective and substantial requirement for the occupational wellbeing of ladyboys. The first is the physical and mental experience, which consists of three main categories, namely "active engagement", "love for work" and "psychological satisfaction". Active engagement means that participants subjectively accept their job and perceive happiness from engaging in this profession. For example, when asked "Do you feel that the work 
process may be more difficult because of the special nature of ladyboy compared to other jobs?'. Participant L3 replied,

It's hard in any kind of work, it's what I like, I feel happy, so it's not hard, I work hard and I never miss a show because it's what I like. When people feel happy they don't feel hard at work.

Love for work and psychological satisfaction express more similar meaning to positive working attitude, indicating that the profession will make them feel happy, therefore, they will not feel pressure when they encounter setbacks or misunderstanding from the audience. They feel psychologically satisfied by engaging in this profession. Especially when asked about the impact of the epidemic on their work, most of the participants maintained their confidence in their careers. They believed that despite the current economic downturn and declining foreign visitors due to the epidemic, this would not affect their love for their work and they would choose to persevere. The second is self-worth. The majority of the participants felt that ladyboy was their career aspiration. Although five were engaged in the profession of ladyboy because of family reasons, they have become increasingly passionate about their profession as they have become more feminine, and they believe that being female and dressing beautifully to bring joy to others is what they endeavor to devoted to. Despite the possibility of lower average life expectancy for various reasons, they are not overly concerned or miserable. When responding to the question regarding life expectancy, participant L8 responded that the moment fireworks bloom is the short life of fireworks. People like us enjoy life in the best youth. There is nothing to be sad about in life.

\section{The Material Dimension}

This dimension mainly includes four categories, namely "access to wealth", "supporting facility", "physical and mental health" and "working for a living", which mainly refers to obtaining income through the career of ladyboys to meet the current or future material life needs. First, when it comes to access to wealth, as a profession, the most direct role of the ladyboy profession is to help them obtain income and maintain living expenses. Through the survey, it is found that the participants' monthly salary is between $8000-30,000$ baht, which is slightly higher in Thailand compared with the remuneration of other jobs. In the interview, many participants expressed satisfaction with their income, which also directly affected their occupational wellbeing. Participant L6's statement that I think this profession is very good and can bring money was similar to that of other participants. This is also consistent with the category of "working for a living". Because ladyboys in Thailand earn higher wages, poorer families raise their sons as girls in the hope that they will become ladyboys and earn income for their families. However, it should be emphasized that their income has been negatively influenced by the COVID-19 epidemic. Nevertheless, they still have full confidence and express love for their career. Secondly, some places in Thailand already have some supporting facilities specially set up for ladyboys, such as special toilets, dressing rooms, etc., but compared with the number of Thai ladyboys, it is far from enough. The places where the performance team of the participants is located do not have corresponding supporting facilities, so they will feel a little embarrassed and at a loss when facing many physiological problems. Finally, regarding the physical and mental health of ladyboys, the long-term use of hormones, and inappropriate living habits, ladyboys were slightly physically worse than other practitioners. In particular, the negative effect of aging on physical appearance will influence the physical and mental health of ladyboys, making them lose enthusiasm for life and declining their physical quality gradually. Therefore, participants aspire to earn more money when they are young and attractive, which can provide security for their future life. Despite the lower average life span for ladyboys, however, with the progress of medical technology, they need to take drugs and receive treatment regularly to improve their life expectancy, which requires financial support.

\section{The Social Dimension}

The social dimension includes the categories of "social support" and "self-identity", where the fulfillment of the ladyboy's occupational role is reflected in the psychological experience of social reputation, perceptions of others, and self-identity. Firstly, social support refers to the perception of the profession by those associated with the ladyboy in society. The survey results demonstrate that social support for the profession of ladyboys in Thailand is relatively high. To begin with, it is reflected in the daily interactions of ladyboys. Through the interviews, it is known that ladyboys have more frequent contact with women than with men, 
during which ladyboy is treated as normal occupational practitioner or even regarded as cute. Compared to other women, ladyboys are very versatile, love to pamper and joke around, therefore, they are very popular, as evidenced by the statement of L6 that I like being with them and they are very helpful, we get along very well. Secondly, social support is reflected in the support and understanding of family members for the profession. All participants stated that their families were very supportive and considerate of their choice. Even those participants from well-off families stressed that their families knew that ladyboy was their dream profession since their childhood and supported them in achieving it. For instance, L12 mentioned that "my mum and dad both understand and want me be a good person." Thirdly, social identity was also reflected as a measure of social support. Participants mentioned that society perceives ladyboys will earn a living through their efforts and are not to be ridiculed or belittled. Fourthly, there will be gender ambiguity moments when managers ignore their status as ladyboys and call them to physical jobs that are supposed to be for men, such as setting up a stage or carrying heavy objects. The majority of the participants mentioned similar situations when they mentally consider themselves to be female while being treated as male. The second category is elf-identity. Having grown up with women, ladyboys consider themselves to be women and feel relaxed with their female friends. Despite their biological masculinity, they do not reject these masculine features in themselves. They see themselves as normal people who work diligently for themselves in a profession that may seem special to others but is not superior or inferior to other professions.

\section{Discussion}

\section{Analysis of Underlying Causes}

From the analysis of the research results above, it can be concluded that the occupational happiness of ladyboys in Thailand is relatively high, mainly reflected in the social dimension of high social support and self-identity; the material dimension of higher income to meet daily needs; and the spiritual dimension of better physical and mental experience, happiness and realization of their values. Traditionally, the prime time of a ladyboy's career is short, there are certain requirements for physical appearance. What's more, the negative effect of increasing age on physical appearance, indulgence caused by psychological gap and long-term use of hormones will greatly shorten the life of ladyboy, and constant performance will bring a great amount of pain and illness. This result despite all the visible negative effects is associated with three factors that may be related to the ladyboy culture in Thailand. ${ }^{23}$ Thai society's attitude towards ladyboys, ${ }^{24}$ and selfidentity. ${ }^{25}$

Firstly, regarding Thai ladyboy culture, the ladyboy has become a special icon in Thailand. There are ladyboy groups in every city in Thailand, ladyboy schools, and even ladyboy beauty contests. The first thing coming to mind when thinking of Thailand is a ladyboy and ladyboy show is the top priority for many people abroad. For Thailand, a ladyboy has become a very important perspective for foreigners to understand Thailand and a form of cultural export from Thailand to other countries. The coverage of ladyboys on magazines, news, internet in Thailand is becoming increasingly open, all featuring ladyboys in a positive and public manner. Secondly, concerning the attitude of Thai society towards ladyboy, the aforementioned increasing media coverage of ladyboys shows that the current Thai society is accepting ladyboys to a high degree, which is also reflected in the survey results, as evidenced by the inclusiveness and support of ladyboy's family and friends for them to achieve their ambitions. Finally, considering the identity of ladyboys themselves, most ladyboys choose this profession because they want to be a woman, performing on stage wishing to be admired and they want to be well rewarded for their work. So without any discrimination from the outside world, they identify themselves as ladyboys to a very high degree. The aforementioned three aspects have an impact on ladyboys' occupational wellbeing. ${ }^{26}$

\section{Improvement Measures}

It is found that although the occupational wellbeing of ladyboys is high, there are still numerous areas that need to be improved and refined, such as the lack of various supporting facilities specifically for ladyboys, absence of policies to support ladyboys to change their gender and policies to protect ladyboys and the inability to secure their livelihood after leaving the acting profession due to aging. To address the above issues, feasible measures are proposed as follows.

\section{Providing More Supporting Facilities for Ladyboys}

Currently, some shopping malls in Thailand are equipped with special toilets for ladyboys, but comparatively, it is 
not enough given the huge number of ladyboys. Since ladyboys are physically male and physiologically female, when it comes to gender classification, they need to be given special facilities, among which is a washroom. Being physically male, their washrooms need to have many of the facilities that a male washroom should have, which can effectively avoid an awkward situation when choosing a washroom specially designed for males or females only. Secondly, there should be more dressing rooms for ladyboys. They are in the performance industry, which requires them to change their clothes more frequently. As Thailand is located in a tropical region with a hot climate, ladyboys' costumes are thin and revealing. Therefore, when they change their clothes, they will expose their original physical features. If they change clothes in a dressing room for females, they will feel uncomfortable, although these females may accept the identity of the ladyboy, they may find it repulsive to see an individual with a male identity in the same dressing room. Meanwhile, ladyboys are physiologically feminine, so they will feel less acceptable when they change clothes in a male dressing room. Therefore, wherever public facilities are divided by gender, there should be specially designed supporting facilities for ladyboys, which is a sign of social justice and progress. ${ }^{22}$

\section{Introducing Policies to Protect and Support Ladyboys}

Thailand is a predominantly Buddhist country that has wide acceptance as well as stereotypes of ladyboys as not being nice. Participant L12 mentioned family support for his profession as well as the wish from his father and mother for him to be a kind good person. Therefore, the relevant authorities should introduce policies to protect ladyboys so that society can understand this group in a more positive manner. Secondly, some supportive policies should be put in place. Firstly, the gender shown on the ID card in Thailand is the first gender and cannot be changed. Secondly, ladyboys are required to participate in the military recruitment process like other males.

The gender on the ID card cannot be modified, which leads to an embarrassing dilemma that ladyboys are personally and socially accepted as female and perceive that they should have the rights and social status that women should enjoy, but they are not entitled to it and cannot be officially recognized as such.

Meanwhile, ladyboys are subject to all the obligations required of Thai men, such as military service. They are required to report to the conscription site, even though they may be exempted from military service by the conscription officer for that they are "physically unfit for military service", which is very unacceptable for a ladyboy who has always lived in a female circle and considers himself a woman. ${ }^{27}$

\section{Providing a Minimum Livelihood After Unemployment}

Ladyboy has had a very positive impact on Thailand. On the one hand, it has increased the visibility of Thailand, as the ladyboy profession has become more widely known and understood, and on the other hand, it has contributed to Thailand's economic development. As mentioned earlier, a ladyboy has become a cultural symbol of Thailand for foreigners, in this sense, it has created a prosperous industry chain and contributed to the development of the Thai economy. Once they are old and not physically attractive anymore, they will be jobless and unwaged. Some ladyboys may find other jobs to make ends meet, and many more lead a more downwardly mobile life, while they also need to take expensive estrogen to maintain their femininity and to treat injuries and illnesses caused by long hours of performance work. It is therefore recommended that the relevant authorities take notice of the ladyboy profession and provide them with basic income security when they are unemployed. A policy could be formulated to award points according to their contribution so that when they leave the performance industry and do not have a major source of income, they can apply to the government for minimum subsistence regularly based on their points. ${ }^{28,29}$

\section{Providing Re-Employment Support for Ladyboys}

For most ladyboys, they have been taught since childhood how to be good ladyboys and they habitually want to earn an income through their appearance and by engaging in activities related to their appearance, so as they age and are not physically attractive, they can continue to make a basic living through their perceived ways. Generally speaking, the ladyboy is usually around 30 years old when leaving the performance team, an age when there are still many possibilities for individuals to take up some other jobs. To protect the life of ladyboy after unemployment, it is not only necessary to provide them with a basic living income, but more importantly, to provide them with job training and skills training, and to combine the skills they have learned as well as the special characteristics of ladyboy's physiological condition to recommend employment positions for them in a targeted manner so that 
ladyboy can be re-employed. On the one hand, they can meet their basic needs, and on the other hand, it can help ladyboys to break away from the sadness and indulgence of losing their beauty and their jobs so that they can find new meaning in their lives. ${ }^{30,31}$

\section{Providing Specialized Medical Services}

Because of the special physiological problems for ladyboys brought by long-term injection or taking hormone drugs and the particularity of the occupation, ladyboys are much more likely to encounter violence or catch sexually transmitted diseases than other occupations. Although the current medical insurance mode in Thailand is universal medical treatment, ie 30 baht medical plan, which indicates that the coverage of medical care can reach more than $75 \%$ of the national population of Thailand. However, such a high coverage will force hospitals to avoid using instrument inspection or prescribing better drugs to reduce costs. Therefore, this medical plan can only meet the needs of ordinary conditions, while special conditions involving ladyboys need to be treated in occupational hospitals. On the other hand, due to the specific nature of ladyboys' sexuality, there is ambiguity in their choice of the department when visiting a doctor in a general hospital for their specific condition. Therefore, it is recommended that specialized medical services be provided for ladyboys by setting up a unit for ladyboys on the one hand, and the other hand, providing categorized treatment for the common and specific conditions of ladyboys. ${ }^{32-35}$

\section{Conclusion}

This paper conducted a qualitative study on "ladyboys' occupational wellbeing" by Nvivo11. The research result indicates that ladyboys' occupational wellbeing is relatively high, mainly in three aspects: social dimension, material dimension, and spiritual dimension. They believe that being a ladyboy is a subjective choice that will enable them to realize their values in life. In addition, they love their job and consider it to be a source of happiness for them. Even though the current epidemic has had a significant impact on their work, they are still committed to their career and are confident about its future. Nevertheless, there are still some shortcomings in Thai society, mainly in terms of lack of supporting facilities, absence of protective and supportive policies, and inability to secure their livelihood after leaving the acting profession. In recent years as society has become more concerned about ladyboys, the special nature and development of its profession have also sparked social reflection. This paper still has certain limitations in the selection of the survey subjects. And it is found from the literature review that there are few studies on ladyboys currently. The only studies focus on ladyboys' daily life and working state, and the research on their professional psychology is not involved. As mentioned earlier, according to the interpretation of the International Labor Organization, occupation is not equal to work, but the sum of similar jobs, which not only affects the material needs of practitioners but also affects their mental and psychological aspects. Especially for a special career like a ladyboy, more attention should be paid to the professional psychological state of practitioners. The investigation and research on their professional well-being just fill the gap of this part of research and expand the research perspective of ladyboys' careers. However, there are still many deficiencies in this study. For example, the selection of survey objects is affected by many objective factors, the number of samples is insufficient, and the survey is concentrated in a certain area, which makes the study somewhat academically limited. In future research, attention should be paid to the needs of ladyboys, and their status, role, and psychological characteristics in society should be analyzed and discussed.

\section{Data Sharing Statement}

The datasets generated during and/or analyzed during the current study are available from the corresponding author on reasonable request. The corresponding author, Bei Lyu is available if the data is requested.

\section{Ethical Approval}

The present study was carried out following the ethical standards of the institutional and national research committees and with the 1964 Helsinki Declaration and later amendments, and all other related ethical commitments. Our study was conducted with the consent of the Ethics Committee of Huaibei Normal University of China and Panyapiwat Institute of Management in Thailand.

\section{Informed Consent}

The corresponding author is sure that informed, written consent was obtained from all participants and was clearly stated. Written informed consent to participate was obtained from the parents/ guardians of the minors included in this study. 


\section{Acknowledgment}

The start-up funding for Ph.D. scientific research of Huaibei Normal University of China (No. 03106098).

\section{Disclosure}

The authors report no conflicts of interest for this work.

\section{References}

1. von Zweck C, Klaiman D, Pattison M. International standard classification of occupations survey report: implications for the world federation of occupational therapists. World Fed Occup Ther Bull. 2017;73(2):80-82. doi:10.1080/14473828.2017.1367460

2. Schwegler U, Nutzi M, Marti A, Trezzini B. Pre- and post-injury job type distributions of individuals with SCI in relation to structural changes in the labor market: a comparative analysis based on findings from the Swiss Spinal Cord Injury Cohort Study. J Spinal Cord Med. 2021;44(1):77-88. doi:10.1080/10790268.2019.1573346

3. Van Horn JE, Taris TW, Schaufeli WB, Schreurs PJG. The structure of occupational well-being: a Study among Dutch Teachers. J Organ Psychol. 2004;77:365-375. doi:10.1348/0963179041752718

4. Lee DJ, Sirgy MJ, Efraty D, et al. A study of quality of work life, spiritual well-being, and life satisfaction. In: Handbook of Workplace Spirituality and Organizational Performance. Me Sharpe; 2003:209-230.

5. Warr P. The measurement of well-being and other aspects of mental health. J Occup Psychol. 1990;63(3):193-210. doi:10.1111/j.2044 8325.1990.tb00521.x

6. Sun YW. Research on occupational well-being: frontier review and new ideas. Adv Psychol. 2020;10(7):959-966. doi:10.12677/ AP.2020.107115

7. Jenni R, Sanna K, Helena L-K, Terhi S, Leena S. Self-conductive interventions by educators aiming to promote individual occupational well-being: a systematic review. Int J Educ Res. 2021;107:1-16. doi:10.1016/j.ijer.2021.101755

8. Duran F, Woodhams J, Bishopp D. The relationships between psychological contract violation, occupational stress, and well-being in police officers. Int J Stress Manag. 2020;28(2):141-146. doi:10.1037/ str0000214

9. Kilponen K, Huhtala M, Kinnunen U, Mauno S, Feldt T. Illegitimate tasks in health care: illegitimate task types and associations with occupational well-being. J Clin Nurs. 2021;30(13-14):2093-2106. doi:10.1111/jocn. 15767

10. Cheung F, Chan W, Arena DF, et al. Sexual identity management strategies and occupational well-being: a latent profile analysis. J Career Dev. 2021;48(4):430-442. doi:10.1177/0894845319856113

11. Johnson CP, Kathleen O. Please, bring me some coffee": illegitimate tasks as the explanation for the relationship between organisational sexism and occupational well-being. GENDER-Zeitschrift für Geschlecht, Kultur und Gesellschaft. 2020;3:S: 124-140. doi:10.3224/gender.v12i3.09

12. Bohlmann C, Rudolph CW, Zacher Z. Effects of proactive behavior on within-day changes in occupational well-being: the role of organizational tenure and emotion regulation skills. Occup Health Sci. 2021;5(18):1-30. doi:10.31234/osf.io/cu7mg

13. Jain A, Hassard J, Leka S, Di tecco C, Iavicoli S. The role of occupational health services in psychosocial risk management and the promotion of mental health and well-being at work. Int J Environ Res Public Health. 2021;18(7):3632. doi:10.3390/ijerph18073632

14. Rinne J, Koskinen S, Leino-Kilpi H, Saaranen T, Salminen L. Selfconductive interventions by educators aiming to promote individual occupational well-being-A systematic review. Int $J$ Educ Res. 2021;107:101755. doi:10.1016/j.ijer.2021.101755
15. Li Y, Zhang RC. Kindergarten teachers' work stress and work-related well-being: a moderated mediation model. Soc Behav Pers. 2019;47 (11):e8409. doi:10.2224/sbp.8409

16. Bartels AL, Peterson SJ, Reina CS. Understanding well-being at work: development and validation of the eudaimonic workplace well-being scale. PLoS One. 2019;14(4):e0215957. doi:10.1371/journal.pone. 0215957

17. Naksing P. Sex Division of Ladyboys [MA thesis]. Bangkok: Humanities school of Thammasat University; 2004.

18. Pearce C, Rychetnik L, Wilson A. The obesity paradigm and the role of health services in obesity prevention: a grounded theory approach. $B M C$ Health Serv Res. 2021;21(1):111. doi:10.1186/s12913-021-06089-w

19. Bryant A. Continual permutations of misunderstanding: the curious incidents of the grounded theory method. Qual Inq. 2021;27(34):397-411. doi:10.1177/1077800420920663

20. Charmaz. Grounded theory. In: Ritzer G, editor. Encyclopedia of Sociology. Cambridge, MA: Blackwell; 2006a.

21. Li HL. Grounded theoretical methods and domestic public management research. Chin Administration. 2015;11:76-81. doi:10.3782/j. issn.1006-0863.2015.11.14

22. Bukalakorn R. The Identity and Communication of Shemale Acting [master's thesis of the school of humanities]. Bangkok: Thammasat University; 2007.

23. Saneaha P. A Study on the Daily Life of Thai Undergraduate Ladyboys [MA thesis], Harbin Institute of Technology; 2018.

24. Sribusdi P. A Study on the Tourism Motivation of Chinese Tourists Going to Thailand to Watch the Show of Ladyboys [MA thesis]. Guangxi University; 2016. Available from: http:/cdmd.cnki.com.cn/Article/ CDMD-10593-1016199753.htm. Accessed December 22, 2021.

25. Alice. Study on the Development of Thai Tourism Industry and Its Impact on Thai Economy [Ph.D thesis]. Jilin University; 2014.

26. Somporn P, Walters L, Ash J. Expectations of rural community-based medical education: a case study from Thailand. Rural Remote Health. 2018;18(4):4709. doi:10.22605/RRH4709

27. Monkey J, Tucker P. Sexual signatures: on being a man or a woman. Oxford, England: England Little Brown; 1975. Available from: https:// psycnet.apa.org/record/1975-22157-000. Accessed December 22, 2021.

28. Nussbaum MC. Gender trouble: feminism and the subversion of identity. New Republic. 1999;220(8):37-45. doi:10.1057/fr.1991.33

29. Saejang J. Overview of entertainment management of tourism destinations: a case study of the ladyboy cabaret show market in Phuket, Thailand. Mediterr J Soc Sci. 2014;5(23):73-85. doi:10.5901/ mjss.2014.v5n23p772

30. Habibah YN, Pratama JA, Iqbal MM. Globalisasi dan Penerimaan LGBTQ+ di ASEAN: studi Kasus Budaya Boys' Love di Thailand [Globalization and Acceptance LGBTQ+ in ASEAN: a Case study of Boys' Love Culture in Thailand]. J Sentris. 2021;2(1):87-103. Indonesian. doi:10.26593/sentris.v2i1.4615.87-103

31. Tangcharoensathien V, Sirilak S, Sritara P, et al. Co-production of evidence for policies in Thailand: from concept to action. $\mathrm{Br} \mathrm{Med} J$. 2021;15(372):m4669. doi:10.1136/bmj.m4669

32. Pochaisan O, Pattanarattanamolee R, Pongphuttha W, et al. Development of an emergency medical services system in Thailand: roles of the universal health coverage and the national lead agency. Emerg Med Australas. 2021;33(4):756-758. doi:10.1111/17426723.13794

33. Marome W, Shaw R. COVID-19 response in Thailand and its implications on future preparedness. Int J Environ Res Public Health. 2021;18(3):1089. doi:10.3390/ijerph18031089

34. Jiang D, Liu J, Sirisrisakulchai J, Sriboonchitta S. Forecasting Thailand inbound tourist flow association for tourism demand. J Phy. 2021;19(21):012063.

35. Baird SL. Reflections from applying intersectionality to a constructivist grounded theory study on intimate partner violence and trauma. Fam Soc. 2021. doi:10.1177/1044389421992296 


\section{Publish your work in this journal}

Psychology Research and Behavior Management is an international, peer-reviewed, open access journal focusing on the science of psychology and its application in behavior management to develop improved outcomes in the clinical, educational, sports and business arenas. Specific topics covered in the journal include: Neuroscience, memory and decision making; Behavior modification and management; Clinical applications; Business and sports performance management; Social and developmental studies; Animal studies. The manuscript management system is completely online and includes a very quick and fair peer-review system, which is all easy to use. Visit http://www. dovepress.com/testimonials.php to read real quotes from published authors. 